\title{
Pig populations at risk of Taenia solium cysticercosis and subsequent financial losses in West and Central Africa
}

\author{
Emmanuel Assana $^{1 *}$ Julius Awah-Ndukum ${ }^{1}$ \\ André Pagnah Zoli ${ }^{1}$ Clément Agnem Etchike ${ }^{1}$ \\ Aristide Sassa Mebenga ${ }^{1}$ Vitalis Chepnda ${ }^{2}$ \\ Meritxell Donadeu ${ }^{3,4}$ Baptiste Dungu ${ }^{5}$
}

\section{Keywords}

Swine, cysticercosis, Taenia solium, simulation models, stochastic models, West Africa, Central Africa, Africa South of Sahara

Submitted: 14 July 2017

Accepted: 5 June 2019

Published: 12 July 2019

DOI: $10.19182 /$ remvt.31257

\begin{abstract}
Summary
Taenia solium cysticercosis is a serious problem for pig breeders and a major public health risk in Africa. There is growing interest in eradicating porcine cysticercosis in endemic areas to reduce or eliminate indirectly human taeniasis and neurocysticercosis. However, there is a lack of reliable data on pig populations affected by the disease because of the unavailability of specific diagnostic tools. A stochastic model helped to estimate pig populations at risk of T. solium cysticercosis, prevalence of the disease, and related financial losses in West and Central Africa. Results revealed that over 16 million pigs (95\% confidence interval [Cl]: 13.7-20.1) were kept in conditions favorable to T. solium cysticercosis. The estimated number of pigs infected with this disease was 6.89 million (95\% Cl: $4.26-9.88)$, i.e. $30.0 \%$ prevalence (95\% Cl: $26.6-43.8)$. The estimated direct financial losses for pig farmers and traders were 165 million euros (95\% Cl: 117.2-213.0). The study highlights the needs to raise awareness on the situation and implement control measures against $T$. solium taeniasis/cysticercosis in both regions.
\end{abstract}

- How to quote this article: Assana E., Awah-Ndukum J., Zoli A.P., Etchike C.A., Mebenga A.S., Chepnda V., Donadeu M., Dungu B., 2019. Pig populations at risk of Taenia solium cysticercosis and subsequent financial losses in West and Central Africa. Rev. Elev. Med. Vet. Pays Trop., 72 (2): 73-81, doi: 10.19182/remvt.31257
1. The University of Ngaoundere, School of Veterinary Medicine and Sciences, PO Box 454, Ngaoundere, Cameroon.

2. Ministry of Livestock, Fisheries and Animal Industries, National Program for the Prevention and Control of Zoonoses, Yaounde, Cameroon.

3. The University of Melbourne, Faculty of Veterinary and Agricultural Sciences, Veterinary Clinical Centre, Werribee, Victoria 3030, Australia.

4. Initiative for Neglected Animal Diseases (INAND), Midrand, South Africa.

5. MCI, Santé animale, Mohammedia 28810, Maroc

* Corresponding author

Tel.: +23779856332

Email: assana_e@yahoo.fr; e.assana@univ-ndere.cm

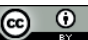

https://creativecommons.org/licenses/by/4.0/ definitive hosts for the adult tapeworm, which lodges in the intestines of individuals. In the conditions where latrines are unavailable or not used, eggs of the tapeworm are released with the human feces in the environment. Following ingestion by pigs, eggs hatch and oncospheres develop in pig tissues causing porcine cysticercosis. The life cycle of the parasite is completed when uncooked contaminated pork is consumed by humans, leading to intestinal adult tapeworm infection (taeniasis). Humans may also be infected by cysticerci following accidental ingestion of $T$. solium eggs. In humans, cysticerci may establish in the brain, causing neurocysticercosis (NCC). NCC-associated epilepsy was recently considered as the parasitic food-borne infection having the largest number of disability adjusted life years (DALY) in the world (Torgerson et al., 2015). There has been a growing urge to eliminate $T$. solium porcine cysticercosis using vaccination and treatment of pigs to reduce or eliminate indirectly the burden of human taeniasis and neurocysticercosis in endemic areas including Africa. However, there is a dearth of information on the epidemiology of the disease and pig production systems in Africa. Comprehensive reliable epidemiological data on the size and distribution of pigs at risk of cysticercosis and infected pigs are essential to understand the disease importance in pig populations for an effective control 
program. Moreover, as recently highlighted, an economic assessment used more extensively would identify priority animal diseases to be tackled (Roger et al., 2017).

Funding agencies have a limited research interest in pig production in Africa. Subsequently, pigs are the least well-known of all major species of domestic livestock in the continent (Blench, 2000). In most countries of sub-Saharan Africa, government involvement in pig production is linked to regulation with regard to surveillance of the African swine fever. Pig production and marketing systems are not structured. Lack of interest in controlling T. solium cysticercosis and unavailability of appropriate and specific diagnostic tools have been reported (Assana et al., 2013; Braae et al., 2015).

The diagnostic tools used to collect epidemiological data on porcine cysticercosis are tongue palpation, meat inspection and serological tests. The carcass inspection of pigs described in the literature concerns mainly abattoir surveys for the examination of different muscles for the presence of $T$. solium cysticerci. There are few studies on porcine cysticercosis using village-based field surveys in Africa. On the other hand, tongue inspection is applied for detection of cysts in live pigs in certain areas in endemic countries (Assana et al., 2001; Dorny et al., 2004). In many cases, some infected pigs are excluded before reaching the abattoir or the pig markets (Praet et al., 2010). Moreover, the sensitivity of tongue palpation and meat inspection is low (Dorny et al., 2004). Evidently, porcine T. solium cysticercosis is underreported in the epidemiological studies using these methods. Nevertheless, both tongue palpation and meat inspection methods have a specificity approaching $100 \%$ indicating that cysticerci identified by these methods classify the animal as true infected with $T$. solium cysticercosis (Dorny et al., 2004). Therefore, at the present time meat inspection and tongue palpation are the only practical and cost-effective techniques available for the diagnosis of porcine $T$. solium cysticercosis under field conditions (Guyatt and Fèvre, 2016).

Concerning immunodiagnosis of porcine cysticercosis, the most frequently used test in epidemiological studies conducted in West and Central Africa is a monoclonal antibody-based antigen detection ELISA (B158/B60 Ag-ELISA), which does not allow differentiating T. solium from T. hydatigena (Dorny et al., 2004; Dermauw et al., 2016). It is clear that this serological test has overestimated the real prevalence of porcine $T$. solium cysticercosis in the endemic areas of West and Central Africa, where T. hydatigena was present in studies carried out during the past two decades (Assana et al., 2013; Braae et al., 2015). In the studies conducted in Africa, the prevalence of meat and tongue cyst-positive pigs was lower than the prevalence of antigen-positive pigs (Guyatt and Fèvre, 2016). Subsequently, critical views have been raised to indicate that most positive pigs presented in the epidemiological studies in Africa in the past decades using Ag-ELISA are often not infected with any cysticercosis (Lightowlers et al., 2016).

Concerning the burden of $T$. solium cysticercosis, there is only one source of data on estimated losses caused by the disease in West and Central Africa published more than a decade ago (Zoli et al., 2003). New data have been obtained on cysticercosis since 2003 in many other countries in the regions. It has been suggested that the previous estimates of the occurrence of porcine T. solium infection using Ag-ELISA in Africa in the past decades and the burden estimates for pig farmers have to be adjusted (Dermauw et al., 2016). In this context, our study used data from tongue and meat inspection in combination with information on pig farming systems in a comprehensive stochastic model to determine the size of pig populations at risk of T. solium infection, the expected prevalence of the disease, and related financial losses for pig farmers in West and Central Africa. We emphasized the agricultural burden caused by this zoonosis in the regions.

\section{MATERIALS AND METHODS}

\section{Study area}

In this study, 28 countries are considered to belong to West and Central Africa regions (Zoli et al., 2003). South Sudan has been included in the Central Africa region since its independence in 2011. All major species of domestic livestock are reared in these regions.

Central Africa comprises 13 countries (Angola, Burundi, Cameroon, Central African Republic, Chad, Congo, Democratic Republic of Congo, Equatorial Guinea, Gabon, Rwanda, Sao Tome and Principe, South Sudan and Zambia). According to country statistics (www.geonames. org), the region has a population of 167,082,216 inhabitants in a total area of 7,734,364 square kilometers. Extending from the equatorial forest of Congo Basin to the Saharan desert zone of the north of Chad, it holds various characteristics and climates. The population is largely engaged in rural activities that include crop and animal productions.

West Africa comprises 15 countries (Benin, Burkina Faso, Cabo Verde, Cote d'Ivoire, Gambia, Ghana, Guinea, Guinea Bissau, Liberia, Mali, Niger, Nigeria, Senegal, Sierra Leone, Togo). The total human population is $296,203,410$ in an area of $5,012,903 \mathrm{~km}^{2}$ with the highest population in Nigeria (www.geonames.org). The area holds much sociocultural, economic, demographic and religious diversity. Similarly to Central Africa, the human population is mainly engaged in agricultural activity.

Cultural and linguistic evidences and local pig breeds strongly suggest that pig keeping was common in many areas of West and Central Africa before the introduction of exotic breeds from Europe in the fifteenth century (Blench, 2000). Pig production has increased during the past decade from 5\% to 10\% (Porphyre, 2009; FAO, 2017). However, the African swine fewer remains a major limiting factor for the development of modern pig production in both regions.

\section{Pig populations at risk of infection with T. solium cysticercosis}

The parameters used to estimate pig populations at risk of $T$. solium cysticercosis infection in West and Central Africa are presented in Tables I and II and Figure 1. These parameters were gathered from a comprehensive literature review of published community studies on pig management, environmental conditions favoring T. solium transmission, and epidemiological data on porcine cysticercosis in West and Central Africa. Experts also provided additional unpublished data. Data on pig populations in each country were compiled from the Food and Agriculture Organisation database (FAO, 2017).

\section{Pig management systems}

Pig management systems in West and Central Africa are presented in Table II. Pigs were mainly kept by small-scale farmers under traditional systems, which represented $60-90 \%$ of total pig populations in the regions. Briefly, there were the scavenging system where the pig searched for its own feed, the semi-intensive system where the majority of the feed consisted of domestic waste and the animals were enclosed only during the night, and the intensive system where the animals were provided feed and housing. In the scavenging system, animals had access to home scraps and waste including human feces when latrines were not used. During the cropping and rainy seasons, pigs were kept in enclosures but were released after the crop harvest and dry seasons to roam freely.

\section{Factors favoring porcine T. solium cysticercosis}

An exposure factor for cysticercosis infection is defined in this study as the environment where the life cycle of T. solium is completed. Several conditions favoring $T$. solium transmission have been reported in endemic areas of Africa (Tables I and II). These conditions among 
Table I

Parameters to estimate the number of pigs at risk of Taenia solium cysticercosis infection, and related losses in West and Central Africa

\begin{tabular}{|c|c|c|c|}
\hline Parameters & Distribution & Value/range & References \\
\hline Live pig production & Fixed & $22,562,685$ & $\mathrm{FAO}, 2017$ \\
\hline Live pig population in each country & Fixed & $6,800-7,066,905$ & $\mathrm{FAO}, 2017$ \\
\hline Pork in each country (tons) & Fixed & $115-239,400$ & \\
\hline Herd size (small-scale farmers) & Gamma & $\begin{array}{c}4-10 \\
\text { Probable: } 6.9\end{array}$ & $\begin{array}{l}\text { Survey in Cameroon (Assana, unpubl. data) } \\
\text { Survey in Senegal (A. Teko-Agbo, pers. commun.) }\end{array}$ \\
\hline Population at risk of infection (\%) & Uniform & $60-90$ & Porphyre, 2009 \\
\hline $\begin{array}{l}\text { Prevalence of porcine cysticercosis in each } \\
\text { country determined by tongue or meat exam }\end{array}$ & Uniform & $0.2-39$ & Res. literature (Table III) \\
\hline $\begin{array}{l}\text { Heavily infected pigs destroyed at } \\
\text { slaughterhouses }\end{array}$ & Beta & 13,114 & Survey in Cameroon (G. Nsingo, pers. commun.) \\
\hline Intervention cost (pig treatment/farmer) ( $€$ ) & Uniform & $0.4-1.5$ & Survey in Cameroon (G. Nsingo, pers. commun.) \\
\hline Losses caused by porcine cysticercosis & Fixed & $\begin{array}{l}30 \% \text { of price } \\
\text { of adult pig }\end{array}$ & Praet et al., 2009 \\
\hline Pig price at the market $(€)$ & Uniform & $70-122$ & $\begin{array}{l}\text { Survey in Cameroon (G. Nsingo, pers. commun.) } \\
\text { Survey in Senegal (A. Teko-Agbo, pers. commun.) } \\
\text { Survey in Benin (Goussanou et al., 2013) }\end{array}$ \\
\hline Pig price at the trader's level $(€)$ & Uniform & 90-180 & \\
\hline Num. of pigs a farmer can sell / year & Uniform & $2-6$ & Survey in Cameroon (Assana, unpubl. data) \\
\hline
\end{tabular}

Table II

Pig management systems as main sources of exposure to Taenia solium infection in West and Central Africa

\begin{tabular}{|c|c|c|c|c|c|}
\hline Systems & Housing & Ownership & Feeding & \% (systems) & References \\
\hline \multirow[t]{2}{*}{ Scavenging } & None & Often communal & None & $5-9$ & $\begin{array}{l}\text { Antunes et al., } \\
2015\end{array}$ \\
\hline & $\begin{array}{l}\text { Construction from local } \\
\text { materials } \\
\text { Confinement at night and } \\
\text { during a period in the year }\end{array}$ & Individual & $\begin{array}{l}\text { None or only when animals are } \\
\text { confined during a short period in } \\
\text { the year }\end{array}$ & $20-40$ & $\begin{array}{l}\text { Assana et al., } \\
\text { 2001; Antunes et } \\
\text { al., } 2015\end{array}$ \\
\hline Herded & None & Individual & Seasonal diet & & Blench, 2000 \\
\hline Tethered & None & Individual & Household waste & $1-5$ & Blench, 2000 \\
\hline Semi-intensive & $\begin{array}{l}\text { Semi-permanent } \\
\text { construction from local } \\
\text { materials }\end{array}$ & $\begin{array}{l}\text { Individual } \\
\text { smallholders }\end{array}$ & $\begin{array}{l}\text { Household waste, millet brew } \\
\text { waste, millet and maize bran and } \\
\text { sometimes grown grass } \\
\text { Animal are free during the dry } \\
\text { season when crops are harvested } \\
\text { in many rural areas }\end{array}$ & $60-90$ & $\begin{array}{l}\text { Blench, 2000; } \\
\text { Gweba et al., } \\
\text { 2010; Ngowi et } \\
\text { al., 2017 }\end{array}$ \\
\hline Intensive & $\begin{array}{l}\text { Modern pen made of } \\
\text { concrete with zinc roofing } \\
\text { Semi-permanent } \\
\text { construction from local } \\
\text { materials }\end{array}$ & $\begin{array}{l}\text { Urban-based } \\
\text { entrepreneurs and } \\
\text { businessmen } \\
\text { Small size intensive } \\
\text { pig farm in rural areas }\end{array}$ & $\begin{array}{l}\text { Agro-industrial by-products } \\
\text { Household waste and } \\
\text { concentrate in small-size pig } \\
\text { farms }\end{array}$ & 10 & $\begin{array}{l}\text { Ngwing et al., } \\
2012\end{array}$ \\
\hline
\end{tabular}

others include poor quality of life in rural areas, inadequate access to latrines, financial and knowledge constraints leading to major limitations to improved pig management and latrine building, open defecation enhanced by a lack of knowledge regarding transmission of the parasite, financial barriers to implement control measures, and lack of public sensitization (Ngowi et al., 2017). Except for Muslim localities, all areas in West and Central Africa where pigs are traditionally reared had environmental conditions that favor transmission of $T$. solium cysticercosis.

\section{Epidemiological data on porcine cysticercosis}

Epidemiological data showed irregular reporting of porcine cysticercosis in West and central Africa; the diagnostic methods used were 


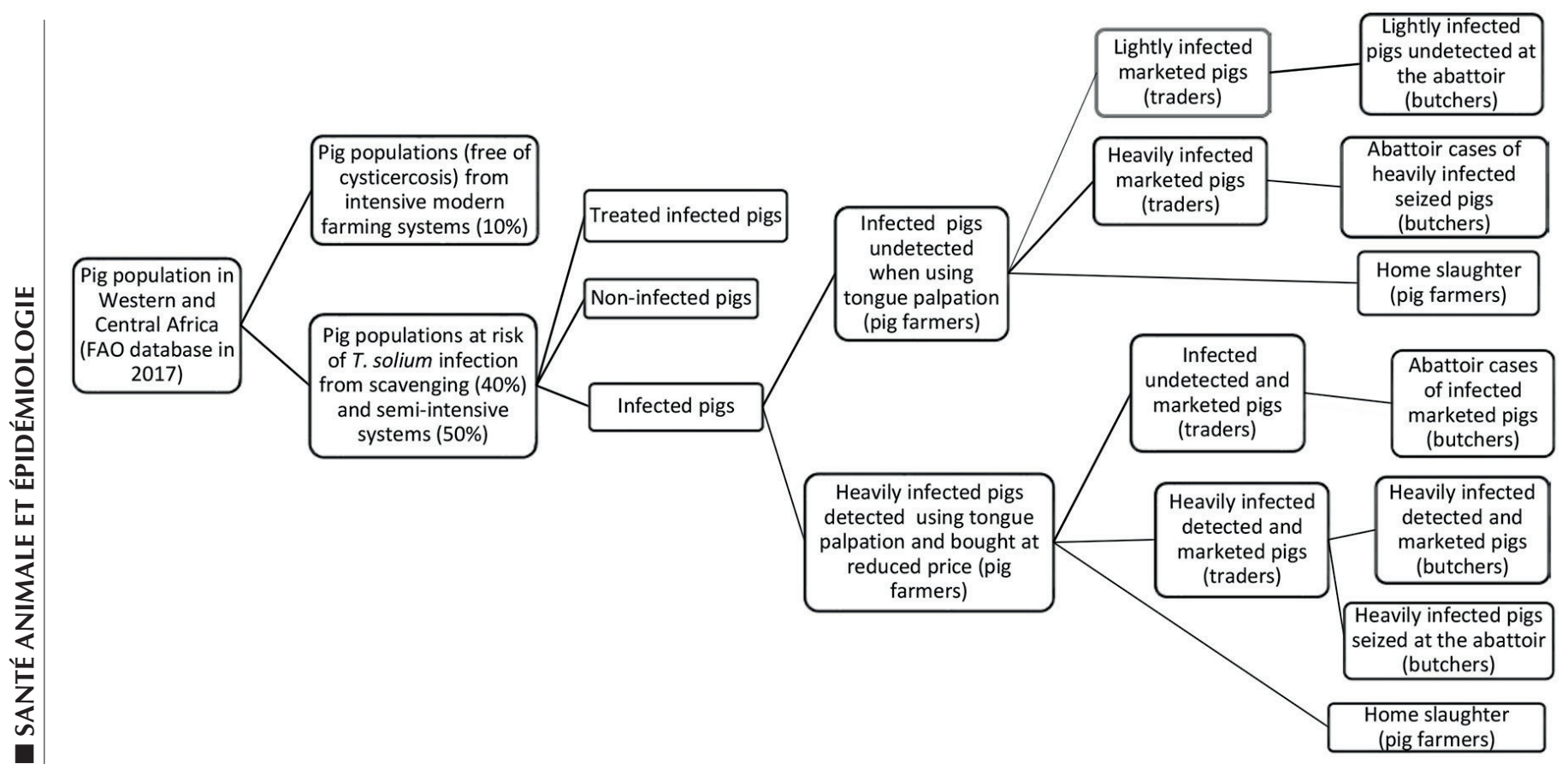

Figure 1: Flowchart to estimate the number of pigs at risk of Taenia solium infection and infected pigs in West and Central Africa.

tongue examination, meat inspection and serology (Table III). However, the extensive seroepidemiological data available on porcine cysticercosis were not used in this study. Cross-reaction between T. hydatigena and T. solium in serological tests could overestimate the real

\section{Table III}

Taenia sp. prevalence in pigs from tongue or meat inspection in West and Central Africa

\section{Countries}

\section{Angola}

Benin

Burkina Faso

Burundi

Cameroon

Chad

Cote d'Ivoire

DRC

Gambia

Ghana

Nigeria

Rwanda

Senegal

Togo

Zambia

\section{DRC: Democratic Republic of Congo}

Prevalence

$(\%)$

6.8

$3.7-8.4$

$0.6-30^{*}$

2-39

11-22

$16.2-26$

2.5

5.5-10

0.2

11.7

5.8-20.5

20

1.2

17

10.8
References

Kama, 1998

Goussanou et al., 2013

Geerts et al.; 2004, Dermauw et al., 2016

Assana et al., 2001;

Ngwing et al., 2012

Assana et al., 2001

Geerts et al., 2004

Praet et al., 2010

Secka et al., 2010

Permin et al., 1999

Onah and Chiejina, 1995 .

Gweba et al., 2010

Geerts et al., 2004

Secka et al., 2010

Dumas et al., 1990

Sikasunge et al., 2008
Newell et al.,1997

* This prevalence at abattoir level is underestimated. In Burkina Faso pigs perceived to be infected based on tongue palpation are rarely sent to official abattoirs (Dermauw et al., 2016). The seroprevalence of porcine cysticercosis (antigen detection) is approximated 40\% (Ganaba et al., 2011; Dermauw et al., 2016) within which PCR results showed that only one quarter could be T. hydatigena antigen. Thus $30 \%$ of pigs infected with $T$. solium were detected at farm level by tongue palpation and excluded from the abattoir. prevalence of porcine $T$. solium cysticercosis in endemic areas where T. hydatigena was present. Although data on T. hydatigena in pigs have been reported in a few countries including Nigeria (Fabiyi, 1979), Ghana (Permin et al., 1999), Burkina Faso (Dermauw et al., 2016) and Zambia (Chembensofu et al., 2017), this parasite could be common in pigs in West and Central Africa along with T. solium. Moreover, transient antibody responses and short-term antigen presence have been reported in T. solium cysticercosis serology in humans (Mwape et al., 2013), which might be the case for porcine cysticercosis.

\section{Annual financial losses caused by porcine cysticercosis}

The pork trade chain involves farmers, traders, butchers, retailers and consumers (Figure 1). In many areas of endemic countries, traders examine the pig's tongue and the pig's price depends on the presence or absence of cysts. Once purchased, the trader transports the pig to a butcher or a retailer. The latter will make sure that the pig's tongue is free of cysts. At the abattoir, the entire infected animal can be lost. It is assumed that pork with a high cyst burden is more detectable than pork with a low cyst burden. In the present study, economic losses for pig keepers were estimated based on $30 \%$ reduction of the price of a cysticercosis-infected pig in Cameroon (Praet et al., 2009; Ngwing et al., 2012). The purchase price of a healthy pig has been reported in Benin (Goussanou et al., 2013) and Cameroon (Ministry of Livestock, Fisheries and Animal Industries) and ranges from 70 to 122 euros (45,000 to 80,000 CFA francs from Central Africa [XAF]) and 90 to $180 €(60,000$ to $118,000 \mathrm{XAF})$ at the level of pig farmers and traders, respectively. For the economic losses at the level of butchers, the number of carcasses destroyed or seized in the abattoir of Yaounde in Cameroon (G. Nsingo, 2013, pers. commun.), Senegal (A. Teko-Agbo, 2012, pers. commun.) and Benin (Goussanou et al., 2013) was assumed to be similar to those in the other countries of West and Central Africa.

The cost of interventions such as treatment of animals was estimated based on information obtained from Cameroon, Tanzania and Uganda (E. Assana and S. Gumbi, unpubl. data). In Cameroon, pig farmers usually try to treat their pigs if they find them infected during routine tongue palpation before bringing them to the market. For this purpose, they do self-prescription and use indigenous products (E. Assana, unpubl. data). 


\section{$R$ model}

We used the R model described by Praet et al. (2009) and Trevisan et al. (2017). Briefly, R software (Development Core Team, version 3.4.0) uses the Markov Chain Monte Carlo (MCMC) technique and allows calculating 95\% confidence intervals. The parameters compiled in Table I were used to build the R function. A flowchart was constructed to estimate the proportion of pig populations at risk of infection with $T$. solium and of infected animals (Figure 1).

To estimate the prevalence of porcine cysticercosis, the sensitivity of meat inspection and tongue examination as visual tests was considered to be between $20-50 \%$ and specificity was assumed to be $100 \%$ (Dorny et al., 2004). Consequently, many infected carcasses were missed and only the heavily infected ones were detected by these tests. Moreover, observations in abattoirs in Cameroon showed that about $10 \%$ of infected pigs were condemned during veterinary inspections (G. Nsingo, unpubl. data), the rest was marketed at normal prices. Similar findings have been reported in Benin (Goussanou et al., 2013). The expected true number of infected pigs and true prevalence of porcine cysticercosis were computed with the $\mathrm{R}$ model based on the characteristics of tongue and meat inspection as diagnostic tools (Table IV). The R function was simulated from 10,000 to 200,000 iterations to compute the optimal number of pigs at risk of $T$. solium infection, the number of infected pigs, the expected prevalence of porcine cysticercosis, and the related cost. Different probabilistic distributions were used according to the information available on each of the parameters in Table I. The $\mathrm{R}$ model is presented in Supplementary Materials I, II and III.

\section{RESULTS}

\section{Pig population size at risk of T. solium infection}

Pigs are present in all countries of West and Central Africa (Table V). Angola, Burkina Faso, Cameroon and Nigeria had the highest pig population at risk of $T$. solium cysticercosis infection. The total

\section{Table IV}

Two-by-two contingency table containing parameters used in the stochastic model to estimate the prevalence of Taenia solium in pigs in West and Central Africa

\begin{tabular}{llll} 
& & \multicolumn{2}{c}{ Outcome of tongue/meat inspection } \\
\cline { 2 - 4 } & Proportion of pigs found infected with cysticerci & Proportion of pigs found free of cysticerci & Total \\
\hline $\begin{array}{ll}\text { Proportion of infected pigs } \\
\text { Proportion of infection-free pigs }\end{array}$ & $\mathrm{P} \times \mathrm{Se}$ & $\mathrm{P} \times(1-\mathrm{Se})$ & $\mathrm{P}$ \\
\hline Total & $\mathrm{P} \times \mathrm{Se}+(1-\mathrm{P}) \times(1-\mathrm{Sp})$ & $(1-\mathrm{P}) \times \mathrm{Sp}$ & $1-\mathrm{P}$ \\
\hline
\end{tabular}

$\mathrm{P} \times \mathrm{Se}+(1-\mathrm{P}) \times(1-\mathrm{Sp})=\mathrm{P}^{\prime} ; \mathrm{P}=\left(\mathrm{P}^{\prime}+\mathrm{Sp}-1\right) /(\mathrm{Se}+\mathrm{Sp}-1)$

where $\mathrm{P}$ ' represents the proportion of pigs found infected with cysticerci of T. solium during tongue/meat inspection, $\mathrm{P}$ the true prevalence of T. solium cysticercosis in pigs (estimated by the stochastic model presented in Suppl. Mat.), Se the sensitivity of tongue/carcass inspection comprised between 0.20 and 0.50 (Dorny et al., 2004), and Sp the specificity of tongue/carcass inspection and is equal to 1 .

\section{Table V}

Live pig populations at risk of Taenia solium cysticercosis in West and Central Africa

\begin{tabular}{|c|c|c|c|c|c|}
\hline \multicolumn{3}{|c|}{ West Africa } & \multicolumn{3}{|c|}{ Central Africa } \\
\hline Countries & Pig populations $^{\mathrm{a}}$ & Pig populations at risk ${ }^{b}$ & Countries & Pig populations $\mathrm{s}^{\mathrm{a}}$ & Pig populations at risk \\
\hline Benin & 431,000 & 356,784 & Angola & $2,874,400$ & $2,546,849$ \\
\hline Burkina Faso & $2,345,800$ & $2,066,010$ & Burundi & 479,197 & 391,525 \\
\hline Cabo verde & 85,000 & 73,317 & Cameroon & $1,800,000$ & $1,600,984$ \\
\hline Cote d'Ivoire & 370,000 & 228,212 & CAR & $1,000,000$ & 848,251 \\
\hline Gambia & 8,192 & 6,522 & Chad & 33,500 & 28,327 \\
\hline Ghana & 682,000 & 500,003 & Congo & 95,000 & 79,591 \\
\hline Guinea & 106,000 & 80,593 & DRC & 991,727 & 828,616 \\
\hline Guinea Bissau & 463,000 & 322,135 & Equatorial Guinea & 6,800 & 5,966 \\
\hline Liberia & 290,000 & 192,573 & Gabon & 220,000 & 140,315 \\
\hline Mali & 77,288 & 66,760 & Rwanda & $1,015,000$ & 878,426 \\
\hline Niger & 42,500 & 32,954 & Sao Tome \& P. & 35,000 & 21,275 \\
\hline Nigeria & $7,066,905$ & $4,563,176$ & South Sudan & $14,406^{\mathrm{c}}$ & 11,217 \\
\hline Senegal & 397,400 & 280,589 & Zambia & $1,100,000$ & 964,736 \\
\hline Sierra Leone & 65,000 & 50,797 & & & \\
\hline Togo & 467,570 & 342,471 & & & \\
\hline Total & $12,897,655$ & $9,162,896$ & & $9,665,030$ & $8,346,078$ \\
\hline
\end{tabular}

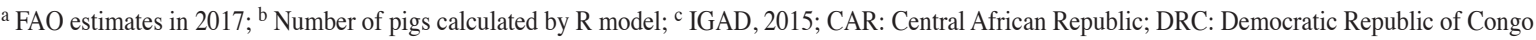


pig population in the regions represented an annual income for pig farmers estimated at 2.16 billion euros (95\% CI: 1.61-2.72). About $16,914,656$ (95\% CI: 13,706,008-20,137,836) pigs were reared in conditions favoring $T$. solium cysticercosis. The distribution of pigs at risk of $T$. solium infection is presented in Figure 2.

The number of pig populations at risk of T. solium cysticercosis for each country was calculated based on dominant scavenging and semi-intensive production systems presented in the literature $(60-90 \%$ of pig populations). Each of the four leading countries in pig production had at least 1,000,000 pigs under systems favoring T. solium. Although

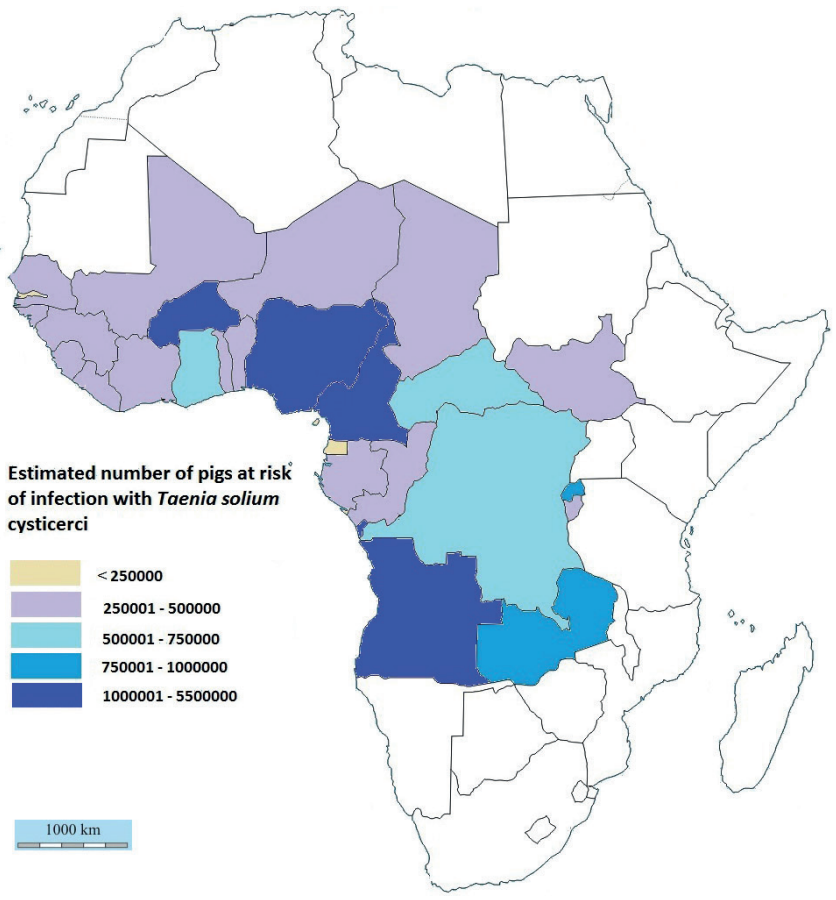

Figure 2: Distribution of pig populations at risk of infection with Taenia solium cysticercosis in West and Central Africa. published data on T. solium porcine cysticercosis are lacking for some countries, the transmission occurs in all areas where pigs are reared under traditional conditions. For example, no information is available on the pig production of South Sudan in FAO database, but the Intergovernmental Authority on Development (IGAD) estimated in 2015 that the country had 14,406 pigs reared under traditional systems by communities in Upper Nile State, suggesting that $T$. solium transmission may be occurring between humans and pigs in the country.

\section{Number of pigs infected with $\mathrm{T}$. solium and related financial losses}

Based on reported prevalence rates of porcine cysticercosis obtained by tongue palpation and meat inspection in 15 countries of West and Central Africa, the R model estimated the annual number of infected pigs at 6,895,868 (95\% CI: 4,262,734-9,881,338), i.e. a prevalence of $30.05 \%$ (95\% CI: 26, 62-43, 80). Tables VI and VII show the estimated number of infected pigs and expected prevalence of porcine cysticercosis by country, respectively. Over $90 \%$ of the total estimated infected pigs were found in the fifteen countries. Nigeria, Angola, Cameroon, Burkina Faso and Zambia had the highest populations of infected pigs.

Visual methods (tongue palpation and meat inspection) estimated 2,384,048 (95\% CI: 1,691,797-3,073,781) heavily infected pigs which were not entirely condemned, but marketed at low prices. Financial losses caused by the reduction of the price of infected pigs were estimated at 165 million euros (95\% CI: 117,241,510-213,013,030) for the 15 countries. In the case of massive infection, the entire animal was destroyed at the abattoir. This constituted a loss for butchers estimated at 243,935 pigs (95\% CI: 121,669-413,172) for the 15 countries (Table VIII). The annual cost related to condemnation and destruction of carcasses for butchers was estimated at 33 million euros (95\% CI: $14,500,103-51,113,219)$. The cost of drugs and indigenous products used by pig farmers trying to prevent reduced prices for their infected animals was estimated at $0.4-1.53 €$ per pig. The related annual cost of treatment was estimated at 16 million euros (95\% CI: 6,896,975-27,672,763) for the 15 countries. The average direct loss for farmers in each country was estimated at 4.5 million euros (95\% CI: 3,248,250-5,901,660).

\section{Table VI}

Estimated annual number of Taenia solium infected pigs detected by tongue and meat inspection and financial losses at the farmer's level in 15 countries of West and Central Africa

\begin{tabular}{|c|c|c|c|c|}
\hline \multirow[t]{2}{*}{ Countries } & \multicolumn{2}{|c|}{ Expected infected pigs } & \multicolumn{2}{|c|}{ Estimated costs } \\
\hline & Num. & $95 \% \mathrm{CI}$ & $(€)$ & $95 \% \mathrm{Cl}$ \\
\hline Angola & 114,938 & $32,967-196,978$ & $3,310,218$ & $949,474-5,671,959$ \\
\hline Benin & 25,866 & $13,550-38,150$ & 744,986 & $391,218-1,098,836$ \\
\hline Burkina & 445,036 & $156,052-735,259$ & $12,841,614$ & $4,495,506-21,188,191$ \\
\hline Burundi & 98,301 & $13,993-182,463$ & $2,826,854$ & $402,911-5,256,576$ \\
\hline Cameroon & 297,155 & $202,993-391,212$ & 855,809 & $5,848,790-11,263,248$ \\
\hline Chad & 6,932 & $5,357-8,506$ & 199,591 & $154,252-244,915$ \\
\hline Cote d'Ivoire & 4,816 & $596-9,026$ & 138,758 & $17,049-260,150$ \\
\hline DRC & 84,290 & $51,335-117,214$ & $2,428,083$ & $1,478,563-3,376,686$ \\
\hline Gambia & 87 & $11-166$ & 2,476 & $316-4,780$ \\
\hline Ghana & 61,351 & $41,933-80,801$ & $1,768,107$ & $1,207,526-2,327,645$ \\
\hline Nigeria & 954,226 & $450,915-1,457,024$ & $27,451,674$ & $12,984,877-41,970,159$ \\
\hline Senegal & 10,124 & $4,294-15,982$ & 291,657 & $123,321-460,425$ \\
\hline Togo & 53,829 & $29,354-78,219$ & $1,547,678$ & $844,934-2,252,332$ \\
\hline Rwanda & 111,758 & $24,956-198,431$ & $3,224,256$ & $714,412-5,718,441$ \\
\hline Zambia & 115,528 & $99,848-131,182$ & 115,485 & $2,874,787-3,777,235$ \\
\hline
\end{tabular}

CI: confidence interval; DRC: Democratic Republic of Congo 
Table VII

Expected true number of infected pigs and true prevalence of Taenia solium cysticercosis in West and Central Africa

\begin{tabular}{|c|c|c|c|c|}
\hline \multirow[t]{2}{*}{ Countries } & \multicolumn{2}{|c|}{ Expected true infected pigs } & \multicolumn{2}{|c|}{ Expected prevalence } \\
\hline & Num. & $95 \% \mathrm{Cl}$ & $(\%)$ & $95 \% \mathrm{Cl}$ \\
\hline Angola & 328,662 & $267,057-403,218$ & 11.4 & $9.3-14.0$ \\
\hline Benin & 73,722 & $60,120-89,989$ & 17.1 & 13.9-20.9 \\
\hline Burkina Faso & $1,262,892$ & $1,071,005-1,467,324$ & 53.8 & $45.6-62.5$ \\
\hline Burundi & 277,864 & $236,923-320,912$ & 58.0 & $49.4-67.0$ \\
\hline Cameroon & 843,373 & $708,284-991,436$ & 46.8 & $39.3-55.0$ \\
\hline Chad & 19,647 & $16,673-22,668$ & 58.6 & $49.8-67.7$ \\
\hline Cote d'Ivoire & 13,756 & $11,087-17,052$ & 3.7 & $2.0-4.6$ \\
\hline DRC & 240,011 & $196,871-290,532$ & 24.2 & $19.85-29.3$ \\
\hline Gambia & 248 & $192-318$ & 3.0 & $2.3-3.9$ \\
\hline Ghana & 174,696 & $174,696-211,224$ & 25.6 & $21.0-30.9$ \\
\hline Nigeria & $2,710,800$ & $2,254,888-3,225,081$ & 38.3 & $31.9-45.6$ \\
\hline Senegal & 28,919 & $23,393-35,684$ & 7.3 & $5.8-8.9$ \\
\hline Togo & 152,875 & $126,357-183,386$ & 32.7 & $27.0-39.2$ \\
\hline Rwanda & 317,091 & $262,467-380,562$ & 31.2 & $25.9-37.5$ \\
\hline Zambia & $3,28,524$ & $271,175-395,121$ & 29.9 & $24.6-35.9$ \\
\hline
\end{tabular}

CI: confidence interval; DRC : Democratic Republic of Congo

\section{Table VIII}

Plausible losses caused by Taenia solium cysticercosis in West and Central Africa

\begin{tabular}{lcccc} 
& \multicolumn{2}{c}{ Infected pigs } & \multicolumn{2}{c}{ Estimated losses } \\
\cline { 2 - 5 } & Num. & $\mathbf{9 5 \%} \mathbf{C l}$ & $\mathbf{( € )}$ & $\mathbf{9 5 \%} \mathbf{C l}$ \\
\hline Heavily infected marketed pigs & $2,384,048$ & $1,691,797-3,073,781$ & $165,214,534$ & $117,241,510-213,013,030$ \\
Heavily infected seized or destroyed pigs & 243,935 & $121,669-413,172$ & $32,931,961$ & $14,500,103-51,113,219$ \\
Pig treatment cost & & & $16,307,742$ & $6,896,975-27,672,763$
\end{tabular}

CI: confidence interval

\section{DISCUSSION}

Studies on the estimated losses caused by porcine cysticercosis in West and Central Africa are scarce. A rough estimation for the two regions using a conservative estimation method (Zoli et al., 2003) and a stochastic approach limited to West Cameroon (Praet et al., 2009) have been reported. Our study is the first to estimate the broader picture of the agricultural burden of T. solium cysticercosis in West and Central Africa using Monte Carlo simulations. The results showed that the highest estimated numbers of expected infected pigs and pigs at risk of infection with T. solium were mainly in five countries: Nigeria, Angola, Cameroon, Burkina Faso and Zambia. However, a high proportion of infected pigs has been reported in Chad, particularly in the south of the country where people are not Muslim and rear pigs (Assana et al., 2001), as well as in a few communities particularly of the Upper Nile State, in a dominant South Sudan Muslim population rearing pigs (IGAD, 2015). Although Nigeria ranked first in pig production in West and Central Africa (about $4 \%$ of the country total domestic livestock population) and with a high prevalence of $T$. solium cysticercosis in pigs, $80 \%$ of these pigs are found in non-Muslim areas of the subhumid north, and south Guinea savannah zones of the country (Gweba et al., 2010). These findings suggest that isolated pig rearing communities in predominantly Muslim countries including Northern Africa could be endemic for the zoonosis (T. solium cysticercosis in pigs and human taeniasis). Moreover, the number of pigs reared under free roaming/scavenging systems is increasing following the growing demand for meat in urban areas (Porphyre, 2009; Assana et al., 2013), with the plausible subsequent increase of the prevalence of porcine cysticercosis in endemic areas.

The modern pig production systems, which can stop the life cycle of $T$. solium, are not progressing in Africa because of the poor conditions of pig farmers (Kagira et al., 2010). Although great sociocultural, economic, demographic and religious diversities exist in countries of West and Central Africa, variations in pig management systems within the regions are assumed marginal. In addition, similar pig management systems have been reported in countries of Eastern and Southern Africa (Ngowi et al., 2004; Pondja et al., 2010; Thomas et al., 2013) indicating that T. solium cysticercosis affects all areas where pigs are reared under traditional systems.

The expected prevalence of $30.05 \%$ calculated in our study is similar to that reported by Guyatt and Fèvre (2016). In a recent study, Braae et al. (2015) used a Bayesian framework to estimate and map-informed district-level prevalence of porcine cysticercosis in Africa. A prevalence above $60 \%$ that included the results from serological tests was estimated for some districts. Prevalences higher than $60 \%$ in these studies might have been overestimated because of cross-reactions between T. solium and T. hydatigena. Another reason might be the high sensitivity of the serological tests, because in all the studies conducted to date in Africa on porcine cysticercosis, the prevalence in meat and tongue cyst-positive pigs was lower than that in antigen-positive pigs (Guyatt and Fèvre, 2016). 
The direct financial loss caused by porcine cysticercosis estimated by Zoli et al. (2003) at about 25,201,088 € was more than three times lower than that estimated in our study. This difference could be related to the increase in the pig population size in the last decade and the MCMC method used in this study. The mean direct annual loss per country for farmers, traders and butchers in West and Central Africa estimated at 4.5 million euros was higher than 3 million USD of potential loss estimated by Trevisan et al. (2017) in Tanzania in East Africa. The loss is expected to increase following the growing demand for pork in urban areas in West and Central Africa (Porphyre, 2009). A recent study carried out in Zambia to assess the perceptions of the communities regarding pig management showed that confinement of pigs was not seen as an acceptable method to control porcine cysticercosis (Thys et al., 2016). In Burkina Faso, a similar behavior of pig farmers was described. Confinement of animals and construction of latrines are considered too economically constraining by pig farmers (Ngowi et al., 2017). However, they have expressed their willingness to prevent porcine cysticercosis (Ngowi et al., 2017): this disposition could facilitate the adoption of available control tools against this disease. In the past, several attempts have been made to control the disease. The most common actions cited in the literature are community mass chemotherapy, health education, programs to stimulate the use of latrines, improved meat inspection of pigs (Garcia et al., 2006). However, none of these approaches have been very successful. Recently, vaccination of pigs in combination with oxfendazole treatment was successful in eliminating T. solium transmission in Cameroon, Peru and Nepal (Assana et al., 2010; Garcia et al., 2016, Poudel et al., 2019).

\section{- CONCLUSION}

T. solium cysticercosis affects pig populations and thus financially affects pig farmers, traders and butchers in West and Central Africa. The public health burden of $T$. solium taeniasis/cysticercosis complex was not assessed, but the high number of estimated infected pigs provided evidence that taeniasis and neurocysticercosis-associated epilepsy in humans are serious health problems in the regions. In a future study, the public health aspect of this zoonosis will be explored. However, the current results emphasize the need to introduce effective and sustainable interventions for managing the health of human and pig populations in the regions. There could be minimal intervention strategies targeting pigs in the endemic areas. Vaccination and treatment of pigs could be the key interventions to reduce indirectly the burden of human taeniasis and neurocysticercosis (Poudel et al., 2019). The endemic countries with the highest pig populations at risk of T. solium infection could be targeted in priority.

\section{Acknowledgments}

This study was supported by the special allocation account for research in higher education in Cameroon.

\section{Author contributions statement}

EA was the principal investigator. EA, JAN and APZ conceived, designed and coordinated the study. EA and JAN designed R models and carried out the statistical analysis and interpretation. EA, JAN, CAE, ASM, VC, MD and BD participated in the preparation of the manuscript. All authors have read and approved the final version of the manuscript.

\section{REFERENCES}

Antunes A.C.L., Vieira S., Malta M., Nunes T., Vaz Y., 2015. Swine production on Maio Island, Cape Verde: a household survey. Rev. Port. Cienc. Vet., 110 (595-596): 155-159
Assana E., Kyngdon C.T., Gauci C.G., Geerts S, Dorny P., De Deken R., Anderson G.A., et al., 2010. Elimination of Taenia solium transmission to pigs in a field trial of the TSOL18 vaccine in Cameroon. Int. J. Parasitol., 40: 515-519, doi: 10.1016/j.ijpara.2010.01.006

Assana E, Lightowlers M.W., Zoli A.P., Geerts S., 2013. Taenia solium taeniosis/cysticercosis in Africa: risk factors, epidemiology and prospects for control using vaccination. Vet. Parasitol., 195 (1-2): 14-23, doi: 10.1016/j. vetpar.2012.12.022

Assana E., Zoli P.A., Sadou H.A., Nguekam, Voundou L., Pouedet M.S.R., Dorny P., et al., 2001. Prevalence of porcine cysticercosis in Mayo-Danay (North Cameroon) and Mayo-Kebbi (Southwest Chad). Rev. Elev. Med. Vet. Pays Trop. 54 (2): 123-127, doi: 10.19182/remvt.9790

Blench R.M., 2000. A history of pigs in Africa. In: The origins and development of African livestock: Archaeology, genetics, linguistics and ethnography (Eds. Blench R.M., MacDonald K.C). UCL Press, 355-367

Braae U.C., Saarnak C.F.L., Mukaratirwa S., Devleesschauwer B., Magnussen P., Johansen M.V., 2015. Taenia solium taeniosis/cysticercosis and the co-distribution with schistosomiasis in Africa. Parasit. Vectors, 8: 323, doi: 10.1186/ s13071-015-0938-7

Chembensofu M., Mwape K.E., Van Damme I., Hobbs E., Phiri I.K., Masuku M., Zulu G., et al., 2017. Re-visiting the detection of porcine cysticercosis based on full carcass dissections of naturally Taenia solium infected pigs. Parasit. Vectors, 10, 572, doi: 10.1186/s13071-017-2520-y

Dermauw V., Ganaba R., Cissé A., Ouedraogob B., Millogod A., Tarnagda Z., Van Hul A., et al., 2016. Taenia hydatigena in pigs in Burkina Faso: A cross-sectional abattoir study. Vet. parasitol. (230): 9-13, doi: 10.1016/j.vetpar.2016.10.022

Dorny P., Phiri I.K., Vercruysse J., Gabriel S., Willingham III A.L., Brandt J., Victor B., et al., 2004. A Bayesian approach for estimating values for prevalence and diagnostic test characteristics of porcine cysticercosis. Int. J. Parasitol., 34 (5): 569-576, doi: 10.1016/j.ijpara.2003.11.014

Dumas M., Grunitzky K., Belo M., Dabis F., Deniau M., Bouteille B., Kassankogno Y., et al., 1990. Cysticercosis and neurocysticercosis: epidemiological survey in North Togo. Bull. Soc. Path. Exot., 83 (2): 263-274

Fabiyi J.P., 1979. Gastro-intestinal helminths of the pig on the Jos Plateau, Nigeria: relative prevalence, abundance and economic significance. J. Helminthol., 53 (1): 65-71, doi: 10.1017/S0022149X00005757

FAO, 2017. Statistical databases. FAO, Rome, Italy

Garcia H.H., Gonzalez A.E., Gilman R.H., Moulton L.H., Verastegui M., Rodriguez S., Gavidia C., et al., for the Cysticercosis Working Group in Peru, 2006. Combined human and porcine mass chemotherapy for the control of T. solium. Am. J. Trop. Med. Hyg., 74: 850-855, doi: 10.4269/ajtmh.2006.74.850

Garcia H.H., Gonzalez A.E., Tsang V.C.W., O’Neal S.E., Zavalaga F.L., Gonzalvez G., Romero J., et al., for the Cysticercosis Working Group in Peru. 2016. Elimination of Taenia solium transmission in Northern Peru. N. Engl I. Med., 374 (24): 2335-2344, doi: 10.1056/NEJMoa1515520

Geerts S., Zoli A., Nguekam J.P., Brandt J., Dorny P., 2004. The taeniasis-cysticercosis complex in West and Central Africa. South East Asian J. Trop. Med. Public Health, 35 (suppl. 1): 262-265

Goussanou J.S.E., Kpodekon T.M., Saegerman C., Eric Azagoun E., Youssao A.K.I., Farougou S., Praet N., et al., 2013. Spatial distribution and risks factors of porcine cysticercosis in southern Benin based meat inspection records. Int. Res. Microbiol., 4 (8): 188-196

Guyatt H.L., Fèvre E.M., 2016. Lingual palpation for porcine cysticercosis: a rapid epidemiological tool for estimating prevalence and community risk in Africa. Trop. Med. Int. Health, 21 (10): 1319-1323, doi: 10.1111/tmi.12760

Gweba M., Faleke O., Junaidu A., Fabiyi J.P., Fajinmi A.O., 2010. Some risk factors for Taenia solium cysticercosis in semi-intensively raised pigs in Zuru, Nigeria. Vet. Italiana, 46 (1): 57-67

IGAD, 2015. The contribution of livestock to the South Sudan economy. Report. IGAD, Nairobi, Kenya, 33

Kagira J.M., Kanyari W.N., Maingi N., Githigia S.M., N'gang'a J.C., Karuga J.W., 2010. Characteristics of the smallholder free-range pig production system in Western Kenya. Trop. Anim. Health Prod., 42 (5): 865-873, doi: 10.1007/ s11250-009-9500-y

Kama K.L., 1998. Porcine and bovine cysticercosis in the south of Angola. In: Abstract Book of the 9th Int. Conf. Association of Institutions of Tropical Veterinary Medicine, Harare, Zimbabwe, 14-18 Sept., 1998, 62

Lightowlers M.W., Garcia H.H., Guaci C.G., Donadeu, M., Abela-Ridder B., 2016. Monitoring the outcomes of interventions against Taenia solium: options and suggestions. Parasite Immunol. 38 (3): 158-169, doi: 10.1111/pim.12291 
Mwape K.E., Phiri I.K., Praet N., Speybroeck N., Muma J.B., Dorny P., Gabriël S., 2013. The incidence of human cysticercosis in a rural community of eastern Zambia. PloS Negl. Trop. Dis. 7 (3): e2142, doi: 10.1371/journal. pntd.0002142

Newell E., Vyungimana F., Geerts S., Van Kerkhoven I., Tsang V.C.W., Engels D., 1997. Prevalence of cysticercosis in epileptics and members of their families in Burundi. Trans. R. Soc. Trop. Med. Hyg., 91 (4): 389-391, doi: 10.1016/ S0035-9203(97)90251-0

Ngowi H.A., Kassuku A.A., Maedab G.E.M., Boa M.E., Carabin H., Willingham III A.L., 2004. Risk factors for the prevalence of porcine cysticercosis in Mbulu District, Tanzania. Vet. Parasitol., 120 (4): 275-283, doi: 10.1016/j. vetpar.2004.01.015

Ngowi H., Ozbolt I., Millogo A., Dermauw V., Somé T., Spicer P., Jervis L.L., et al., 2017. Development of a health education intervention strategy using an implementation research method to control taeniasis and cysticercosis in Burkina Faso. Infect. Dis. Poverty, 6 (1): 95, doi: 10.1186/s40249-017-0308-0

Ngwing N.A., Poné J.W., Mbida M., Zoli P.A., Njakoi H., Bilong, C.F., 2012. A preliminary analysis of some epidemiological factors involved in porcine cysticercosis in Bafut and Santa subdivision, North West Region of Cameroon. Asian Pac. J. Trop. Med. 5 (10): 814-817, doi: 10.1016/S1995-7645(12)60149-7

Onah D.N., Chiejina S.N., 1995. Taenia solium cysticercosis and human taeniasis in the Nsukka area of Enugu State, Nigeria. Ann. Trop. Med. Parasitol., 89 (4): 399-407, doi: 10.1080/00034983.1995.11812968

Permin A., Yelifari L., Bloch P., Steenhard N.P., Nansen P., 1999. Parasites in crossbred pigs in the Upper East Region of Ghana. Vet. Parasitol., 87 (1): 63-71, doi: 10.1016/S0304-4017(99)00159-4

Pondja A., Neves L., Mlangwa J., Afonso S., Fafetine J., Willingham III A.L., Thamsborg S.M., et al., 2010. Prevalence and risk factors of porcine cysticercosis in Angonia District, Mozambique. PLoS. Negl. Trop. Dis., 4 (2): e594, doi: 10.1371/journal.pntd.0000594

Porphyre V., 2009. Enjeux et contraintes des filières porcines en Afriques de I'Ouest. Grain Sel, 46-47 : 26-27

Poudel I., Sah K., Subedi S., Singh K.D., Kushwaha P., Colston A., Gauci C., et al., 2019. Implementation of a practical and effective pilot intervention against transmission of Taenia solium by pigs in the Banke district of Nepal. PLoSNegl. Trop. Dis., 3 (2): e0006838, doi: 10.1371/journal.pntd.0006838

\section{Résumé}

Assana E., Awah-Ndukum J., Zoli A.P., Etchike C.A., Mebenga A.S., Chepnda V., Donadeu M., Dungu B. Populations porcines exposées au risque de cysticercose à Taenia solium et pertes économiques encourues en Afrique de l'Ouest et centrale

La cysticercose à Taenia solium est un problème majeur pour les éleveurs de porcs et représente un risque important pour la santé publique en Afrique. II y a un intérêt croissant pour éradiquer la cysticercose porcine dans les zones endémiques afin de réduire ou d'éliminer indirectement le téniasis et la neurocysticercose chez les humains. Cependant, les données fiables sur les populations porcines impactées par la cysticercose sont insuffisantes en raison d'un manque d'outils de diagnostic spécifiques. Un modèle stochastique a permis d'estimer les populations porcines à risque de cysticercose à T. solium, la prévalence de cette maladie et les pertes économiques associées en Afrique de l'Ouest et centrale. Les résultats ont montré que plus de 16 millions de porcs (intervalle de confiance à $95 \%$ [IC] :13,7-20,1) étaient maintenus dans des conditions favorables à la cysticercose à T. solium. Le nombre de porcs infectés par cette maladie a été estimé à 6,89 millions (IC $95 \%: 4,26-9,88$ ), soit une prévalence de 30,0\% (IC $95 \%$ : $26,6-43,8)$. Les pertes économiques directes pour les éleveurs de porcs et les revendeurs ont été estimées à 165 millions d'euros (IC $95 \%$ : $117,2-133,0)$. L'étude souligne la nécessité d'informer sur le problème et de mettre en œuvre des mesures de lutte à la fois contre le téniasis et la cysticercose à T. solium dans les deux régions.

Mots-clés : porcin, cysticercose, Taenia solium, modèle de simulation, modèle stochastique, Afrique occidentale, Afrique centrale, Afrique au sud du Sahara
Praet N., Kanobana K., Kabwe C., Maketa V., Lukanu P., Lutumba P., Polman K., et al., 2010. Taenia solium cysticercosis in the Democratic Republic of Congo: how does pork trade affect the transmission of the parasite? PLoS Negl. Trop. Dis. 4 (3): e817, doi: 10.1371/journal.pntd.0000406

Praet N., Speybroeck N., Manzanedo R., Berkvens D., Nforninwe N.D., Zoli A., Quet F., et al., 2009. The disease burden of Taenia solium cysticercosis in Cameroon. PLoS Negl. Trop. Dis., 3: e406, doi: 10.1371/journal.pntd.0000406

Roger F.L., Solano P., Bouyer J., Porphyre V., Berthier D., Peyre M., Bonnet P. 2017. Advocacy for identifying certain animal "diseases as neglected". PLoS Negl. Trop. Dis., 11 (9): e0005843, doi: 10.1371/journal.pntd.0005843

Secka A., Marcotty, T., De Deken R., VanMarck E., Geerts S., 2010. Porcine cysticercosis and risk factors in The Gambia and Senegal. J. Parasitol. Res., 2010: doi: 10.1155/2010/823892

Sikasunge C.S., Phiri I.K., Phiri A.M., Siziya S., Dorny P., Willingham III A.L., 2008. Prevalence of Taenia solium porcine cysticercosis in the Eastern, Southern and Western provinces of Zambia. Vet. J., 176 (2): 240-244, doi: 10.1016/j. tvjl.2007.02.030

Thomas L.F., De Glanville W.A., Cook E.A, Fèvre E.M., 2013. The spatial ecology of free-ranging domestic pigs (Sus scrofa) in western Kenya. BMC Vet. Res., 9: 46, doi: 10.1186/1746-6148-9-46

Thys S., Mwape K., Lefèvre P., Dorny P., Phiri A.K., Marcotty T., Phiri I.,K., et al., 2016. Why pigs are free roaming: communities perceptions, knowledge and practices regarding pig management and taeniosis/cysticercosis in a Taenia solium endemic area in eastern Zambia. Vet. Parasitol., 225: 33-42, doi 10.1016/j.vetpar.2016.05.029

Torgerson P.R., Devleesschauwer B., Praet N., Speybroeck N., Willingham III A.L, Kasuga F., Rokni M.B., et al., 2015. World Health Organization estimates of the global and regional disease burden of 11 foodborne parasitic diseases, 2010: A data synthesis. PLoS Med., 12 (12): e1001920, doi: 10.1371/journal. pmed.1001920

Trevisan C., Devleesschauwer B., Schmidt V., Winkler A.S., Harrison W., Johansen M.V., 2017. The societal cost of Taenia solium in Tanzania. Acta Trop., 165: 141-154, doi: 10.1016/j.actatropica.2015.12.021

Zoli A., Shey-Njila O., Assana E., Nguekam, Dorny P., Brandt J., Geerts S., 2003. Regional status, epidemiology and impact of Taenia solium cysticercosis in Western and Central Africa. Acta Trop., 87 (1): 35-42, doi: 10.1016/ S0001-706X(03)00053-6

\section{Resumen}

Assana E., Awah-Ndukum J., Zoli A.P., Etchike C.A., Mebenga A.S., Chepnda V., Donadeu M., Dungu B. Poblaciones de cerdos en riesgo de cisticercosis de Taenia solium y consiguientes pérdidas financieras en Africa occidental y central

La cisticercosis por Taenia solium es un problema grave para los criadores de cerdos y un riesgo importante para la salud pública en Africa. Existe un interés creciente en erradicar la cisticercosis porcina en áreas endémicas para reducir o eliminar indirectamente la teniasis humana y la neurocisticercosis. Sin embargo, existe una falta de datos confiables sobre las poblaciones de cerdos afectados por la enfermedad, debido a la falta de disponibilidad de herramientas de diagnóstico específicas. Un modelo estocástico ayudó a estimar las poblaciones de cerdos en riesgo de cisticercosis por $T$. solium, la prevalencia de la enfermedad y las pérdidas financieras derivadas en Africa occidental y central. Los resultados revelaron que más de 16 millones de cerdos (intervalo de confianza del 95\% [IC] 13,7-20,1) fueron mantenidos en condiciones favorables a la cisticercosis por T. solium. El número estimado de cerdos infectados con esta enfermedad fue de 6,89 millones (IC del 95\%: 4,26-9,88), o sea una prevalencia del 30\% (IC del 95\%: 26,6-43,8). La estimación de las pérdidas financieras directas para los criadores y comerciantes de cerdos, fueron de 165 millones de euros (IC del 95\%: $117,2-213,0)$. El estudio destaca la necesidad de crear conciencia sobre la situación e implementar medidas de control contra la teniasis / cisticercosis por T. solium en ambas regiones.

Palabras clave: cerdo, cisticercosis, Taenia solium, modelos de simulación, modelos estocásticos, Africa occidental, Africa central, Africa al sur del Sahara 
